\title{
Study of Cerebellum Structure and Histomorphometry of Local Chicken (Gallus gallus domesticus) Before and After Hatching
}

\author{
Arief Maulana ${ }^{1}$, Dian Masyitha ${ }^{2 *}$, Muslim $\mathrm{Akmal}^{2}$, Sri Wahyuni ${ }^{3}$, \\ Zainuddin $^{2}$, Rosmaidar ${ }^{4}$

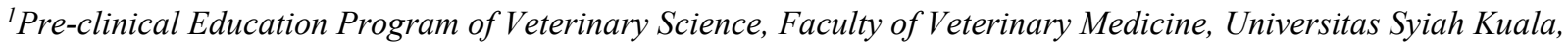 \\ Banda Aceh, Indonesia \\ ${ }^{2}$ Laboratory of Histology, Faculty of Veterinary Medicine, Universitas Syiah Kuala, Banda Aceh, Indonesia \\ ${ }^{3}$ Laboratory of Anatomy, Faculty of Veterinary Medicine, Universitas Syiah Kuala, Banda Aceh, Indonesia \\ ${ }^{4}$ Laboratory of Pharmacology, Faculty of Veterinary Medicine, Universitas Syiah Kuala, Banda Aceh, Indonesia \\ *Corresponding author. Email: dianmasyitha@unsyiah.ac.id
}

\begin{abstract}
Cerebellum is an organ that plays an important role in controlling and coordinating motoric nerves and maintaining body balance. This study aimed to observe the histological and histomorphometric structures of the cerebellum in native chickens before and after hatching. The samples of this study were divided into four groups of different age, namely K1(7th day of incubatiuon), K2 (14th day of incubation), K3 (20th day of incubation), and K4 (7th day after hatching). Each group consists of six chicken cerebellum. Based on the results of macroscopic observations, the size of cerebellum was increased in each group. Histologyobservation showed that in K1, substantiagrisea was present consisting of molecular and granular layers. In K2, substantia alba has been formed, and in K3 and K4, a Purkinje layer was established. Histomorphometry examination showed that substantia alba in each group was decreased, however the size of substantia alba in K3 was not significantly different ( $>>0.05)$ from K4. Substantia grisea has undergone a significant increase $(\mathrm{P}<0.05)$ in each group. It can be concluded that the histological structure of the cerebellum in each age group has developed. In histomorphometric measurements, the substantia alba was decreased in each group. However, the substantiagrisea and its layers has increased in all grups.
\end{abstract}

Keywords: Local chicken, cerebellum, substantia alba, substantia grisea

\section{INTRODUCTION}

The brain is a very complex organ that has many specific parts and functions and varies from species to species. In general, the brain is divided into three main parts, namely the cerebrum, the cerebellum, and the brain stem. These three parts are divided into smaller parts, cerebrospinal fluid, while the outside is covered and protected by 3 layers of brain membrane (meninges) and skull bones [1].

The cerebellum functions to control and coordinate motoric nerves and also to maintain body balance [2] The cerebellum can also regulate body movements from external stimuli to move quickly and precisely, and regulate higher cognitive processes [3]. The cerebellum also determines the parasagittal lines of gene expression [4].
The cerebellum is located in the dorsal medulla oblongata and the pons which is the largest part of the hindbrain. The cerebellum and basal ganglion also play a very important role in regulating body movements which function in maintaining the desired balance and coordination of movements. The division of the cerebellum based on its location, the median part is called the vermis and lateral is called the cerebellum hemisphere. Based on the lobes, the cerebellum is divided into anterior, posterior and fluocunodular lobes [5].

In the process of brain formation, the brain tissue undergo three curves or bends (flexures). The first part is the cefal flexure in the metensefalon area in the form of concave on the ventral part. Second, the pontine flexure 
on the metencephalon is also called the pons, which has a dorsal concave shape. Third, the cervical flexure in the dorsal myensefalon area opens in the ventral part of the brain [2].

Histologically, the cerebellum has three layer structures, namely the molecular stratum, ganglionar stratum (Purkinje), and granulosum stratum. Each of these layers has very different cells. In the molecular stratum there are basket cells, in the ganglionar stratum there are Purkinje cells and in the granulosum layer there are small granular cells that can be seen microscopically [6].

In the embryonic period of chickens, the process of brain formation has started on the first day of incubation and is fully functional on the 7th day of incubation [7] The function of the cerebellum has an important role to play in learning motoric tasks. The size and shape of the cerebellum are related to the type of limb movement of the animal, the center of gravity and the posture of the species itself. The more complex movements an animal has, the more developed is the cerebellum [8].

\section{MATERIALS AND METHODS}

This study was approved by Veterinary Ethics Committee, Faculty of Veterinary Medicine, Syiah Kuala University, Banda Aceh, Indonesia (Ref: 55/KEPH/I/2020). This research was conducted at Histology Laboratory of the Faculty of Veterinary Medicine, Universitas Syiah Kuala, Banda Aceh, from October to December 2019. The materials used in this study include; cerebellum of native chicken, aquades, $\mathrm{NaCl}$ solution of $0.9 \%$, Neutral Buffered Formalin (NBF) $10 \%$ as a fixative solution, graded alcohol $(70 \%, 80 \%$, $90 \%, 95 \%$, and absolute), xilol, paraffin, HematoxylinEosin (HE), and Entellan adhesives ${ }^{\circledR}$.
This study used a completely randomized design (CRD) with a one-way pattern. The sample of this study was divided into four groups and each of these groups containedsix local chicken cerebellum. The number of samples in the study was determined based on the Federer formula [9]. K1 is the 7th day incubation period, $\mathrm{K} 2$ is the 14th day incubation period, K3 is the 20th day incubation period, and $\mathrm{K} 4$ is the 7 th day after hatching. All egg samples used for this study were obtained from the farms of Limpok village, Aceh Besar. The cerebellum sample was then prepared for histological examination using Hematoxylin-Eosin (HE) staining and then observed using a light microscope (Olympus CX31) with $4 \mathrm{x}$ and $10 \mathrm{x}$ magnification. The process of histological preparations refers to the Kiernan method [10].

Histomorphometry of chicken cerebellum focused on the diameter of the white matter, the gray matter which includes the molecular layer, the Purkinje layer, and the granular layer. Data from histological structure of the cerebellum of chicken embryos on the 7th, 14th, 20th day of incubation and after the 7th day of hatching were analyzed descriptively. Histomorphometric measurements were analyzed by ANOVA and further analyzed by Duncan.

\section{RESULTS AND DISCUSSION}

\subsection{Macroscopic Overview}

Macroscopic observations of the cerebellum were carried outThe result showed Table 1 . The data revealed significant increased $(\mathrm{p}<0.05)$ in the weight, length and width of the cerebelum.

Table 1. Morphometric mean and standard deviation of cerebellum weight, cerebellum length, cerebellum width, chicken weight and chicken length

\begin{tabular}{|l|l|l|l|l|}
\hline Morphology & $\mathrm{K} 1$ & $\mathrm{~K} 2$ & $\mathrm{~K} 3$ & $\mathrm{~K} 4$ \\
\hline Cerebellum weight $(\mathrm{gr})$ & - & $0.03 \pm 0.16^{\mathrm{a}}$ & $0.15 \pm 0.04^{\mathrm{b}}$ & $\mathrm{0.18} \pm 0.02^{\mathrm{b}}$ \\
\hline Cerebellum Length $(\mathrm{cm})$ & - & $0.48 \pm 0.15^{\mathrm{a}}$ & $0.83 \pm 0.06^{\mathrm{b}}$ & $0,87 \pm 0.06^{\mathrm{b}}$ \\
\hline Cerebellum width (cm) & - & $0.43 \pm 0.52^{\mathrm{a}}$ & $0.61 \pm 0.02^{\mathrm{b}}$ & $0,66 \pm 0.07^{\mathrm{b}}$ \\
\hline Chicken Weight (gr) & $0.35 \pm 0.09^{\mathrm{a}}$ & $6.97 \pm 1.97^{\mathrm{b}}$ & $31.37 \pm 0.82^{\mathrm{c}}$ & $41.14 \pm 6.40^{\mathrm{d}}$ \\
\hline Chicken Length (cm) & $1.97 \pm 0.10^{\mathrm{a}}$ & $5.78 \pm 0.56^{\mathrm{b}}$ & $8.88 \pm 0.64^{\mathrm{c}}$ & $10.48 \pm 0.27^{\mathrm{d}}$ \\
\hline
\end{tabular}

a,b,c,d Different letter superscripts on the same line indicated significant differences $(\mathrm{P}<0.05)$.

$\mathrm{K} 1: 7^{\text {th }}$ day of incubation period $\mathrm{K} 2: 14^{\text {th }}$ day of incubation $\mathrm{K} 3: 20^{\text {th }}$ day of incubation period.

$\mathrm{K} 4: 7$ day after hatching

Based on Table 1, the mean and standard deviation of cerebellum weight of native chickens at the $14^{\text {th }}$ and $20^{\text {th }}$ day incubation, and 7 th day after hatching are $0,03 \pm$ $0,16 \mathrm{~g} ; 0,15 \pm 0,04 \mathrm{~g}$ dan $0,18 \pm 0,02 \mathrm{~g}$, respectively. The length of cerebellum on $14^{\text {th }}$ and , $20^{\text {th }}$ day incubation, and 7 th day after hatching are $0,48 \pm 0,15 \mathrm{~cm} ; 0,83 \pm$ $0,06 \mathrm{~cm}$ dan $0,87 \pm 0,06 \mathrm{~cm}$, respectively. The width of the cerebellum on $14^{\text {th }}$ and $20^{\text {th }}$ day incubation, and after 7 days of hatching are $, 43 \pm 0,52 \mathrm{~cm} ; 0,61 \pm 0,02 \mathrm{~cm}$ dan $0,66 \pm 0,07 \mathrm{~cm}$, respectively.

The increase in morphometry can also be seen in the weight andlength of the chickens. The mean and standard deviation of chicken weight on the 7th, 14th, 20th day of incubation and after 7 th day of hatching were $0.35 \pm 0.09$ 
g; $6.97 \pm 1.97$ gr; $31.37 \pm 0.82$ gr and $41.14 \pm 6.40$, respectively. The length of chicken at the $7 \mathrm{th}, 14 \mathrm{th}, 20 \mathrm{th}$ day incubation period and 7 days after hatchingare $1.97 \pm$ $0.10 \mathrm{~cm} ; 5.78 \pm 0.56 \mathrm{~cm} ; 8.88 \pm 0.64 \mathrm{~cm}$ and $10.48 \pm$ $0.27 \mathrm{~cm}$, respectively.

Statistical analysis showed that there were significant differences $(\mathrm{P}<0.05)$ in the development of weight, length, and width of the cerebellum as well as weight and length of chickens, so further tests were carried out. In K1 no preparations were carried out because the size was too small and prone to destruction so that measurements were not made.. In the embryonic period, the process of brain formation begins on the first day of incubation and functions perfectly on the 7th day of incubation [7]. The cerebellum is located at the anterior end of the hindbrain and is responsible for the integration of the sensory and motor systems [3]. At the 14th day of incubation the cerebellum has a milky white color, while on the 20th and 7 th day after hatching it has a creamy white color.

\subsection{Overview of Histological Structure}

Based on Figure 1, it can be seen that the cerebellum of chicken embryos on the 7th day of incubation has formed substantia grisea. In this group, the substantia grisea consists of a molecular layer and a granular layer, but the purkinje layer has not yet been formed. In this group there is an empty space called the primordium [11]

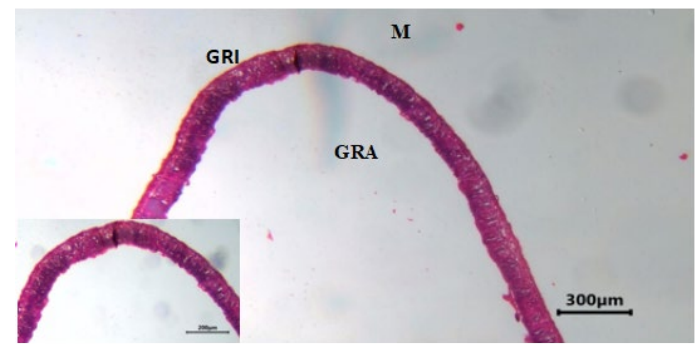

Figure 1 The histological structure of the cerebellum of domestic chicken embryos, the incubation period on the 7th day. Substantia grisea (GRI), molecular layer (M) and granular layer (GRA). HE staining, 4x and 10x magnification.

Based on the results of the study, on the 14th day of incubation (Figure 2), the substantia alba has begun to appear, where the substance alba consists of axons or myelinated nerve fibers in the inner layer of the cerebellum [12]. The substance of alba is the part that forms the medulla cerebellum, this is according to what Abdullah [13] said.

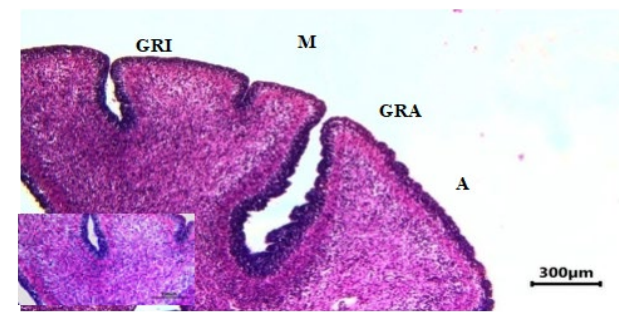

Figure 2 The histological structure of the cerebellum of native chicken embryos in the 14th day of incubation. Grisea substance (GRI), molecular layer (M), granular layer (GRA) and substance alba (A). HE staining, 4x and 10x magnification.

The cerebellum layer of chickens has completed at the incubation period of the 20th day, with a clear appearance of the Purkinje layer (Figure 3). The Purkinje layer is a periform layer of cell bodies [5]. At this age, the cerebellum begin embryonic metabolic activity by Purkinje cells [14] (Akar dan Sue, 2010). The histological structure at the incubation period of the 20th day is very different from the one of 14th day, when the cerebellum still looks loose yet dense as shown on the 20th day.

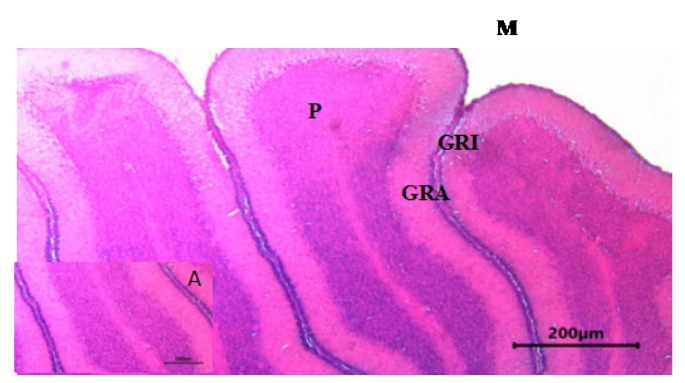

Figure 3 The histological structure of the cerebellum of chicken embryos, the incubation period of the 20th day. Grisea substance (GRI), molecular layer (M), granular layer (GRA), white matter (A) and Purkinje layer (P). HE staining, 4x and 10x magnification.

The histological structure in the cerebellum of chickens after the 7th day of hatching had begun to be compact and tidy. In this group, the cerebellum begins to coordinate the body's movement system [15] and also the balance of these native chickens. The structure of the cerebellum already has many fissures and sulci that develop [16] rapidly with increasing age of native chickens as shown in Figure 4.

\subsection{Histomorphometric Measurement}

Histomorphometry is a method of measuring cells or tissues to study the shape and activity of cells by measuring the volume, thickness, length and width of a cell or tissue [17]. In this study, histomorphometric measurements were carried out to measure the thickness 
of the cerebellum layer to see the development in each of the different age groups, the measurement of the thickness of the layer was focused on the alba substance and the grisea substance which consisted of molecular layers, granular layers and Purkinje layers. Measurements of each layer thickness were taken three

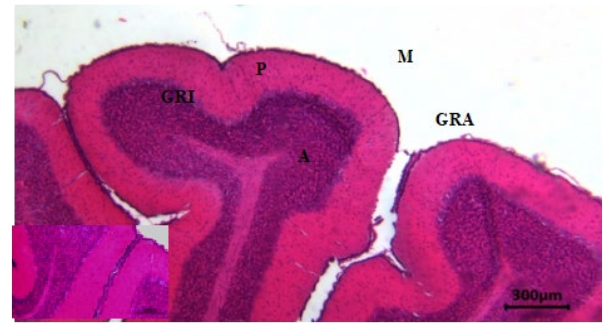

Figure 4 Histological structure of chicken embryos cerebellum after 7 th day of hatching. Grisea substance (GRI), molecular layer (M), granular layer (GRA), white lines in the area of each layer to be measured and the average was taken [18] also carried out the field of view 5 times for each layer measurement. The histomorphometric measurement table for the substantia alba and grisea can be seen in Table 2 .

matter (A) and Purkinje layer (P). HE staining, 4x and 10x magnification.

In Table 2, the mean and standard deviation of the thickness of the substantia alba in the cerebellum on 14th and , 20th, day of incubation, and 7 days after hatching were $326.02 \pm 84.56 \mu \mathrm{m} ; 169.44 \pm 63.71 \mu \mathrm{m}$; and 156.06 $\pm 33.42 \mu \mathrm{m}$, respectively. Based on statistical analysis there was a significant difference $(\mathrm{P}<0.05)$, so that further tests were carried out. Duncan testrevealed that $\mathrm{K} 2$ was significantly different $(\mathrm{P}<0.05)$ from $\mathrm{K} 3$ and $\mathrm{K} 4$, but $\mathrm{K} 3$ was not significantly different $(\mathrm{P}>0.05)$ from $\mathrm{K} 4$.

Table 2. Mean and standard deviation of thickness of white matter and gray matter

\begin{tabular}{|l|l|l|l|l|}
\hline Substantia & \multicolumn{1}{|c|}{ K1 } & K2 & K3 & K4 \\
\hline Alba $(\mu \mathrm{m})$ & - & $326.02 \pm 84.56^{\mathrm{a}}$ & $169.44 \pm 63.71^{\mathrm{b}}$ & $156.06 \pm 33.42^{\mathrm{b}}$ \\
\hline Grisea $(\mu \mathrm{m})$ & $159.32 \pm 40.18^{\mathrm{a}}$ & $116.40 \pm 26.69^{\mathrm{a}}$ & $387.42 \pm 20.76^{\mathrm{b}}$ & $538.68 \pm 51.20^{\mathrm{c}}$ \\
\hline
\end{tabular}

a,b,c Different letter superscripts on the same line indicated significant differences $(\mathrm{P}<0.05)$.

$\mathrm{K} 1: 7^{\text {th }}$ day of incubation period; K2 $: 14^{\text {th }}$ day of incubation period; K3 $: 20^{\text {th }}$ day of incubation period; K4 7 days after hatching

The thickness of the substantia grisea in the cerebellum of chickens incubation period on day 7, 14, 20 and 7 days after were $159.32 \pm 40.18 \mu \mathrm{m} ; 116.40 \pm$ $26.69 \mu \mathrm{m} ; 387.42 \pm 20.76 \mu \mathrm{m}$; and $538.68 \pm 51.20 \mu \mathrm{m}$ respectively. Statistical analysis showed a significant difference $(\mathrm{P}<0.05)$. Duncan test showed that $\mathrm{K} 1$ was not significantly different $(\mathrm{P}>0.05)$ from $\mathrm{K} 2$, but significantly $(\mathrm{P}<0.05)$ from $\mathrm{K} 3$ and $\mathrm{K} 4$. In $\mathrm{K} 3$ there is a significant difference $(\mathrm{P}<0.05)$ with $\mathrm{K} 4$. The grisea substance consists of molecular, granular and Purkinje layers [19]. The histomorphometric measurement table for molecular, granular and purkinje layers is shown in Table 3 .
According to Table 3, the mean and standard deviation of the thickness of the molecular layer in the cerebellum on $7^{\text {th }}, 14^{\text {th }}, 20^{\text {th }}$ day of incubation, and 7 days after hatching were $71.23 \pm 19.51 \mu \mathrm{m} ; 66.70 \pm$ $13.17 \mu \mathrm{m} ; 139.69 \pm 19.66 \mu \mathrm{m}$; and $247.15 \pm 22.01 \mu \mathrm{m}$, respectivey. From the Duncan test, it was found that K1 was not significantly different $(\mathrm{P}>0.05)$ from $\mathrm{K} 2$, but significantly $(\mathrm{P}<0.05)$ from $\mathrm{K} 3$ and $\mathrm{K} 4$. In $\mathrm{K} 3$ there is a significant difference $(\mathrm{P}<0.05)$ with $\mathrm{K} 4$.

Table 3. Mean and standard deviation of molecular, granular and Purkinje thickness

\begin{tabular}{|l|l|l|l|l|}
\hline Layer & K1 & K2 & K3 & K4 \\
\hline Molecular $(\mu \mathrm{m})$ & $71.23 \pm 19.51^{\mathrm{a}}$ & $66.70 \pm 13.17^{\mathrm{a}}$ & $139.69 \pm 19.66^{\mathrm{b}}$ & $247.15 \pm 22.01^{\mathrm{c}}$ \\
\hline Granular $(\mu \mathrm{m})$ & $82.18 \pm 28.03^{\mathrm{a}}$ & $54.56 \pm 13.75^{\mathrm{b}}$ & $208.99 \pm 17.41^{\mathrm{c}}$ & $270.66 \pm 28.47^{\mathrm{d}}$ \\
\hline Purkinje $(\mu \mathrm{m})$ & - & - & $37.20 \pm 7.21^{\mathrm{a}}$ & $46.93 \pm 8.00^{\mathrm{b}}$ \\
\hline
\end{tabular}

a,b,c,d Different letter superscripts on the same line indicated significant differences $(\mathrm{P}<0.05)$.

$\mathrm{K} 1: 7^{\text {th }}$ day of incubation period .

$\mathrm{K} 2: 14^{\text {th }}$ day of incubation periodK $3: 20^{\text {th }}$ day of incubation period; K4 7 days after hatching.

The mean and standard deviation of the thickness of the granular layer in the cerebellum on $7^{\text {th }}, 14^{\text {th }}, 20^{\text {th }}$ day of incubation, and 7 days after hatching were $82.18 \pm$ $28.03 \mu \mathrm{m} ; 54.56 \pm 13.75 \mu \mathrm{m} ; 208.99 \pm 17.41 \mu \mathrm{m} ;$ and $270.66 \pm 28.47 \mu \mathrm{m}$, respectively. Based on Duncan test, it was found that $\mathrm{K} 1$ was significantly different $(\mathrm{P}<0.05)$ from other groups. The mean and standard deviation of the thickness of the Purkinje layer on the cerebellum of native chickens on $20^{\text {th }}$ day of incubation and after 7 days of hatching were $37.20 \pm 7.21 \mu \mathrm{m}$; and $46.93 \pm 8.00$ $\mu \mathrm{m}$. Based on statistical analysis there was a significant difference $(\mathrm{P}<0.05)$. 
From this study, substantia alba of chicken cerebellum after 14 days of incubationwas very broad, compared to 20 days of incubation.After 7 days of of hatching, substantia laba began to shrink as a result of another layer that starts to develop and pressed on the alba layer. In Table 3, an enlargement of the Purkinje layer was found, this is presumably because the axon fibers begin to penetrate the granular layer and when they enter the alba layer they will get a myelin sheath [6].

\section{CONCLUSION}

Based on the research results, it can be concluded that the histological structure of the cerebellum in each age group has developed. In histomorphometric measurements, the substantia alba decreased in each group. However, the substance of the grisea has increased as well as the layers that are in the substance of the grisea.

\section{AUTHORS' CONTRIBUTION}

All authors equally contributed to the preparation and editing of the manuscript.

\section{ACKNOWLEDGMENT}

The author is thankful to the Faculty of Veterinary Medicine, for the facility provided.

\section{REFERENCES}

[1] R. Supradewi, Otak, musik, dan proses belajar, Buletin Psikologi 18(2) (2010) 56-68.

[2] Y. Sukra, Wawasan Pengetahuan Embrio: Benih Masa Depan, Direktorat Jendral Pendidikan Tinggi Departemen Pendidikan Nasional, Jakarta, 2000.

M. Hanzel, R.J.T. Wingate, T. Butts, Ex vivo culture of chick cerebellar slices and spatially targeted electroporation of granule cell precursors, J. Visual. Exp. (106) (2015) 1-7.

[4] J.C. Lin, C.L. Cepko, Biphacic dispersion of clones containing purkinje cell and glia in the developing chick cerebellum, Dev. Biol. (211) (1999) 177-197.

[5] T.W. Pangestiningsih, I.L.M. Saputra, A.S. Suminar, Anatomi perkembangan serebelum monyet ekor panjang (Macaca fascicularis) pada trimester awal kebuntingan, J. Sain Vet. 32(1) (2014) 117-129.

[6] B.V. Nangoy, S.J.R. Kalangi, T.F. Pasiak, Gambaran mikroskopik pada hewan coba postmortem. J. Biomed. (JBM), 11(1) (2019) 10-16.
[7] E.M. Luqman, B.P. Soenardihardjo, L. Mahaputra, Peranan choline esterase (che) pada pembentukan vesikal otak embrio ayam yang terpapar insektisida karbofuran. Media Kedokteran Hewan, 23(3) (2007) 145-150.

[8] B. Pal, S. Chowdhury, R.K. Ghosh, Comparative anatomical study of the cerebellum of man and fowl, J Anat. Soc. India, 52(1) (2003) 32-37.

[9] W. Federer, Experimental Design, Theory, and Application. Mac. Milan, New York, 1963.

[10] J.A. Kiernan, Histological \& Histochemical Methods: Theory and Practice. $2^{\text {nd }}$ ed. Pergamon Press, Oxford, 1990.

[11] N. Wanmi, B.I. Onyeanusi, J.O. Nzalak, T. Aluwong, Histomorphogenesis of the cerebellum of the grey breasted helmeted guinea fowl (Numida melegris galeata) pre and post hatch, Anim. Mol. Breed. 6(4) (2016) 1-10.

[12] V.P. Eroschenko, Atlas Histologi diFiore dengan Korelasi Fungsional. Edisi 11, Penerbit buku kedokteran EGC, Jakarta, 2010.

[13] S. Abdullah, Anatomical study of the cerebellum in diurnal raptor spesies (Buzzard), Al-Mustansiriyah J. Pharm. Sci. (AJPS). 7(1) (2010) 7-13.

[14] S. Akar, E. Sue, The develpoment of chicken cerebellar cortex and the determination of agnor activity of the purkinje cell nuclei, Belg. J. Zool., 140(2) (2010) 216-224.

[15] S.D. Karam, R.C. Burrouws, C. Logan, S. Koblar, E.B. Pasquale, M. Bothwell, Eph receptors and ephrins in the developing chick cerebellum: relationship to sagittal patterning and granule cell migration, J. Neurosci., 20(17) (2000) 6488-6500.

[16] S.D. Karam, M. Dottori, K. Ogawa, J.T. Henderson, A.W. Boyd, E.B. Pasquale,M. Bothwell, EphA4 is not required for Purkinje cell compartmentation, Develop. Brain Res. (135) (2002) 29-38.

[17] S. Wahyuni, S. Agungpriyono, M. Agil, T.L. Yusuf, Histologi dan histomorfometri testis dan epididimis muncak (Muntiacus muntjak muntjak) pada periode ranggah keras, J. Vet. 13(3) (2012) 211-219.

[18] I. Celik, M. Seker, A. Salbacak, Histological and histomorphometric studies on the cerebellar cortex and silver stained nucleous organizer regions of purkinje neurons in chronic morphine-treated rats, Vet. ARHIV, 88(1) (2018) 75-88.

[19] S. Korobitua, S. Wangko, S.H.R. Ticoalu, Gambaran makroskopik dan mikroskopik otak besar pada hewan coba postmortem. J. e-Biomed. (eBm), 5(1) (2017). 